\title{
STRATEGIES FOR TEACHING WRITING IN EFL CLASS AT A SENIOR HIGH SCHOOL IN INDONESIA ${ }^{1}$
}

\author{
Jurianto, Salimah, and Deny A. Kwary \\ juri.jurianto@gmail.com; salimah.albard@gmail.com; \\ kwary@yahoo.com \\ English Department, Airlangga University, Surabaya
}

\begin{abstract}
Writing skill has been considered the most difficult language skill to master, and teaching the skills has also been not simple. Part of a research report on teaching writing in English at a senior high school in Surabaya, this paper is aimed to demonstrate that English teachers at the school are skillful and resourceful in teaching writing. With reference to 11 elements or strategies of writing instruction discussed in Graham and Perin (2007), five English teachers at the school were interviewed. The interview guide includes 24 questions centered on the 11 elements. Interview results show that the teachers make use of most elements or strategies in their English classes. The teachers explained that such strategies as collaborative writing, sentence combining, prewriting, inquiry activities, and study of models are conducted frequently in the classroom. They found the strategies important and helpful for teaching writing skills in English to their students. The findings indicate that a variety of writing instruction strategies have been part of their teaching practice and that they are experienced in teaching writing skills in English to adolescent students.
\end{abstract}

Key words: collaborative writing, English teachers, senior high school, teaching writing, writing strategies

\begin{abstract}
Abstrak: Keterampilan menulis merupakan keterampilan bahasa yang paling sulit dikuasai, dan pengajaran keterampilan ini juga tidaklah mudah. Makalah ini, yang merupakan bagian laporan penelitian tentang pengajaran menulis Bahasa Inggris di sebuah SMA di Surabaya, bertujuan untuk menunjukkan bahwa guru-guru Bahasa Inggris di SMA tersebut cukup berkompeten dan kreatif dalam mengajar keterampilan
\end{abstract}

\footnotetext{
${ }^{1}$ This is part of a research project funded by the Indonesian Government through the scheme Operational Costs of State-owned University (BOPTN) Year 2013-2014.
} 
menulis. Dengan menggunakan 24 pertanyaan yang mengacu pada 11 elemen atau strategi pengajaran writing yang dilaporkan Graham danPerin (2007), lima guru Bahasa Inggris diwawancarai. Hasil wawancara menunjukkan bahwa guru-guru tersebut menggunakan sebagian besar strategi pengajaran menulis tersebut. Strategi pengajaran seperti menuli ssecara kolaboratif, penggabungan kalimat, pra-menulis, kegiatan-kegiatan penyelidikan, dan pembelajaran contoh-contoh teks sering dilakukan guru dalam pengajaran keterampilan menulis di kelas. Para guru berpendapat bahwa strategi-strategi tersebut penting dan sangat membantu dalam pengajaran keterampilan menulis kepada para siswa. Temuan ini mengindikasikan bahwa para guru Bahasa Inggris telah terlatih dan berpengalaman dalam mengajar keterampilan menulis kepada siswa-siswa remaja.

Kata kunci: menulis secara kolaboratif, guru Bahasa Inggris, sekolah menengah atas, pengajaran menulis, strategi menulis

\section{INTRODUCTION}

The policy of Directorate of Higher Education (Indonesian Ministry of Education), which requires the undergraduate students to publish scientific articles, has not only received different responses from university members, but also produced changes in the implementation of writing courses at university level. The policy also indicates a concern of many parties over low writing skills of college graduates, and the concern seems to describe the practice of teaching writing, not only in college, but also in secondary school. While writing problems both at university and at secondary school need serious attention, improvement of students' writing skills should begin in secondary education, particularly senior high school.

In this global era in which competition is tight, a good command of English, including writing, is necessary. In fact, the ability to write in English well usually also indicates a good level of English proficiency. Writing is a part of literacy because people are called literate if they "can read and write in certain situations and for certain purposes" (Harmer, 2007, p. 323). Similar to reading, writing is a learned skill that cannot be mastered in a short time and needs to be continuously trained. In Hyland' words the learning of literacy "does not occur in a vacuum" (Hyland, 2007, p. 155), which means contexts play an important role. This also suggests that the teaching of writing skills in English in school is crucial and needs to be constantly improved. In order that improvements can take place, it is important to first know what has happened 
Jurianto, Salimah, \& Kawry, D.A., Strategies for Teaching Writing in EFL Class 45 at a Senior High School in Indonesia

to the practice of teaching writing in school, so that some empirical evidence is gained.

However, research that examines the issues of writing is still little compared to research into reading that has been established and its reports are relatively abundant. Based on informal communication with colleagues at other universities, and also articles presented at seminars or conferences on teaching English in Indonesia, research in language teaching in Indonesia tends to focus on classroom action research, which usually serves the need for immediate result for improving class performance. This is not to say that such research is of secondary importance. Therefore, to have a more thorough, holistic picture it is necessary to conduct research on the teaching of writing skills in English with a broader scope that includes the role of teachers and students, the role of teaching materials, and the types of classroom writing activities.

This paper deals with strategies of writing instruction as reported by English teachers at a senior high school in Surabaya, Indonesia. It does not attempt to argue that certain strategies are more effective than others for teaching writing skills. Instead, it portrays what the teachers do and experience with teaching writing in English to high school students, teenagers often described as problem students, but at the same time "the most exiting students" (Harmer, 2007, p. 83). Hopefully, the paper can also add some insights to the intricate nature of teaching writing in English as a foreign language.

\section{LITERATURE REVIEW}

As previously stated, in this competitive era language proficiency is necessary, not only in speaking, but also in reading and writing (Kuo, 2006, p. 219). High literacy is required and becomes a prerequisite for success in education and profession, which means having excellent writing skill is crucial. Therefore, teaching writing in English is important for students, especially in non-English speaking countries. In general teaching writing in English has two major approaches: process and genre/product. Process approach is concerned with phases in writing process, while genre approach requires learners to examine texts they are going to write before they start their own writing (Harmer, 2007, p. 327). 
In Indonesia the genre approach to teaching writing began to be officially adopted when Competency-based Curriculum was effective in 2004, which was then replaced by so-called Educational Unit Level Curriculum, an improved version of 2004 curriculum. This can be clearly seen in the competency standard set in English subject. The formulation of the competency standard of English subject, found in any 2014 curriculum document of English for Senior High School, is as follows:

to express a variety of meanings (interpersonal, ideational, textual) through various interactional and monolog texts, in particular those in the form of descriptive, narrative, spoof/recount, procedure, report, news item, anecdote, exposition, explanation, discussion, commentary, and review.

To date studies about writing in English as a second or foreign language have been varied in both the writing product and the teaching process. Lee (1997), for instance, looked at students' performance in error correction in writing and found that students often failed to notice errors in their writing. Zang (2004) using English writing by Chinese undergraduate students analyzed interactive relationships between the influence of topic, individual writers' stance, and text types produced. Still related to writing products, Espada-Gustilo (2009) studied diagnostic essays of college freshmen and found that most frequently errors at sentence-level include use of punctuation, word form and choice, verb usage, prepositions, run-on and fragments, and noun endings. Regarding teaching process, Lin (2006) focused on the roles that model texts play in teaching writing, and Radia and Stapleton (2008) analyzed the influence of the Internet genres on writing process experienced by undergraduate students as learners of English as a second language (ESL). Finally, Epting, Gallena, Hicks, Palmer and Weisberg (2013) investigated the influence of prewriting and writer characteristics on revision process.

In relation to writing instruction, Graham and Perin (2007) conducted a meta-analysis of the results of research into the influence of writing instruction types on teenagers' writing skills. On the basis of their analysis, they provide recommendations for teaching writing to teenage students. They identify 11 types of teaching writing found to be effective for helping teenage students to write well. The eleven types of writing instruction include writing strategies, summarization, collaborative writing, specific product goals, word processing, sentence combining, prewriting, inquiry activities, process writing approach, study of models, and writing for content learning (Graham \& Perin, 2007). For a more comprehensive discussion, see Dean (2010). The eleven 
Jurianto, Salimah, \& Kawry, D.A., Strategies for Teaching Writing in EFL Class 47 at a Senior High School in Indonesia

types of writing instruction become a reference for creating the interview guide used in this study. The choice is based on the fact that Graham and Perin's identification has been meant for teaching writing to teenage students of grade 4 to grade 12 . Therefore, the types of writing instruction are also appropriate to teach writing to students at senior high school of grade 10, 11 and 12 .

\section{THE STUDY}

The study involved five English teachers and three classes of students (grade 10, 11 and12) at a high school in Surabaya Indonesia. To obtain the data, observation and interview were conducted. The interviews with the five teachers focused on the strategies of teaching writing in English that the teachers reported using in their English classes. The interviews were conducted by using an interview guide, created on the basis of 11 elements of writing instruction identified by Graham and Perin (2007). The findings reported in this paper are the result of interviews with the five English teachers.

\section{DISCUSSION}

Regarding 11 types of writing instructions suggested by Graham and Perin (2007), all the teachers interviewed agreed that they are important for teaching writing skills. However, they also reported not using all of the writing instruction types in the teaching and learning process, the reasons of which differ among teachers. Out of 11 types, eight strategies are frequently used, while the rest are very rarely used. The following are explanations about what strategies and how they have been used by the five English teachers.

Writing strategies, the first type of writing instruction, that include teaching students about strategies for planning, revising, and editing their writing are usually carried out before the teacher gives the task of writing. In the interview, four out of the five teachers reported teaching the writing strategies and incorporating these skills in the lesson plan, and three of them allocating10to 15 minutes for the activity. The writing strategies, however, are not taught at length and in detail because of the limited time available for teaching writing skills. In addition, students do not really need knowledge of writing strategies because, as a teacher pointed out, the writing tasks given are fairly simple, and there are models that can be replicated. This situation may indicate that, while writing strategies are deemed to be important, the adopted approach to teaching writing often reduces important aspects of other 
approach. In this context, the genre approach seems to have overshadowed the process approach, resulting in ignoring the application of writing strategies, which are in fact an equal partner of the genre approach (Dovey, 2010).

Summarization, the second type, as a class activity includes teaching students how to summarize a text. All respondents said that they asked the students to make a summary, but some admitted not teaching the steps of summarizing explicitly. Teaching summary writing is usually done while teaching reading. What the teachers do is limited to guiding the student to find the main idea in the text they are reading. Related to summarizing a text, for example, for the task of writing exposition and explanatory text, students are given a reading text but not asked to summarize the text individually. This kind of activity, in fact, tends to reflect the practice of learned-centered instruction as it provides "some control the student[s]" (Brown, 2007, p. 52).

The implementation of the concept learned-centered instruction seems to be more evident in the next type of writing instruction, collaborative writing, in which students work together to complete a writing task. During the interview all teachers expressed the importance of collaborative writing, but only four out of the five teachers reported frequently having students work together particularly in group. They suggest that group work is more effective, it makes them easier to monitor the activity, and the students have the freedom to divide tasks within the group. In addition, collaborative writing activity aims to facilitate students in completing a writing assignment because the students have varying abilities. In fact, it was found to help improve the quality of writing as well as provide an opportunity to generate ideas and feedback for each other (Storch, 2005). Similar finding was reported in Shehadah (2011) and Dobao (2012). This shows that the English teachers are aware of the advantages of collaborative writing as a strategy for teaching writing.

The next activity type in teaching writing is an explanation of a specific product goal that students need to achieve. The teachers stated that they explicitly explain the purpose of the writing task given through writing directions and explained to the students about the criteria of good writing, especially in relation to the organization of content in accordance with the genre specified. Even an English teacher was there to explain to the students about the assessment rubric that she used. The teachers also said that not explaining the criteria of good writing, due to time constraint, was not a problem because the teachers themselves would assess and provide feedback on the students' writing. In substitution, the teachers would remind the students that their writing should meet the generic structure of a particular text type. 
Jurianto, Salimah, \& Kawry, D.A., Strategies for Teaching Writing in EFL Class 49 at a Senior High School in Indonesia

Setting a goal by the teacher is useful since it helps students have a clear target they have to accomplish. Without a clear purpose, which implies a makingmeaning activity, the students could be disoriented as learners of a second language tend to have "more difficulty with setting [their own] goals" (Weigle, 2005, p. 132).This goal setting needs to be dealt with in advance before the students do writing as part of prewriting activity.

Prewriting is basically a strategy of teaching writing that engages students in activities designed to help them generate ideas for their writing. All teachers stated that they give a prewriting activity to the students before the students work on their writing. This prewriting activity is conducted to make students ready and understand the material they will learn or the task they will work with. Prewriting usually takes the form of brainstorming and elicitation or teacher-led question and answer about the content or genre of the text they will discuss. In addition, as some teachers reported, prewriting is also done by giving the students a theme or topic and asking them in group or in pair to generate ideas for their writing. In this activity the teachers usually ask the students to find as much information as possible about the topic and discuss it in class. The teacher serves as a facilitator, providing help in finding relevant learning sources as well as the appropriate language to use. The activity has another important function since it trains the students to conduct inquiry or information-finding.

Inquiry activities involve students in analyzing concrete data around them to help them generate ideas and develop the content of their writing task. Nearly all teachers frequently provide data and case samples that can be used to generate idea samples for the students' writing. They stated that providing such concrete examples is intended to elicit ideas and inspiration, help students relate the sample to the writing they are going to compose, help them express their ideas in their writing, and attract them to the topic or learning material. The teachers also explained that they sometimes ask students to make a report based on observation and interview. This activity enhances students' exploration and investigation skills, and as a result, their report is supported by concreted ata. Through this activity, the students also learn to do a kind of research, which will develop their analytical skills important for their future study.

A writing instruction type typically conducted by the teachers is a study of models, a strategy that provides the opportunity for the students to read, analyze, and imitate models of good writing. From the interview, all teachers reported giving a model before asking the students to write. They also 
explained that when they provide a text model, they ask the students to examine the structure of the text and its linguistic features such as tense, which is effective in helping the students complete their writing task. In addition, providing models is easy because the teachers simply take the models from the textbooks available to them. This strategy, as the teachers suggest, is not uncommon as it relates closely to the genre approach adopted in the curriculum.

The last type of strategy the teachers frequently use is sentence combining, a grammar-based activity that was found to help improve students' writing skills. In particular, learning to write complex sentences can improve students' writing quality (Graham \& Perin, 2007, p. 18). Most teachers also reported teaching their students sentence combining but not doing it in detail: this is done while the students are working on their writing task, or the teachers specifically teach sentence combining in a grammar lesson. The teachers usually take examples of complex sentences from a reading passage. Teaching a language item, either vocabulary or structure, during a language production activity is a form of realization of the concept 'focus on form' as opposed to 'focus on forms' (Harmer, 2007). 'Focus on form' can indeed be done anytime during the learning process is underway, either as "teacher intervention" or because the students attend to the form and say it to the teacher (Harmer, 2007, p. 53). What is certain is that the 'focus on form' usually occurs naturally as part of learning process when the students are doing a language task.

As has been remarked, the study also found that three writing instruction strategies are rarely implemented by the teachers in their English classes. The three include writing process approach, writing for content learning, and word processing. The writing process approach is complex, requiring a number of tightly connected activities (Graham \& Perin, 2007, p. 19), all helping students to have improved skills in writing. An indication of the infrequent use of the strategy can be seen from different responses of the teachers when asked about the frequency of giving writing tasks to their students. Two teachers answered once a week, another two said once in two weeks, and the other one said three times in a semester. This means that writing opportunities for the students tend to be low. Despite this low frequency, the teachers still pay attention to other important elements in writing process approach, which are, "writing for real readers" and "facilitating student interactions” (Graham \& Perin, 2007, p. 19).

In connection with writing for audiences, the teachers stated that the audience or readers in their students' writing are the teacher and classmates. 
Jurianto, Salimah, \& Kawry, D.A., Strategies for Teaching Writing in EFL Class 51 at a Senior High School in Indonesia

Having specific audiences of their writing helps students in selecting the kinds of information to be conveyed. And the decision about who is going to read their writing is made by the students themselves, again an element of studentcentered learning. Furthermore, the teachers also reported encouraging and facilitating interactions in the classroom. Like in any classes, they always try to create an enjoyable atmosphere, so that writing becomes a fun task. Furthermore, to increase student interactions most of the teachers have students work in groups and use a dictionary. They also monitor the activity and act as a facilitator while students are working on their task in group.

Writing for content learning refers to a teaching strategy that makes use of writing as a means for learning other subjects. Even though the teachers agreed that writing can be used to learn other fields and that learning English can be done through learning other subjects, they reported not specifically using the strategy. Instead, they argued, they give more emphasis on their students generating and developing ideas related to the students' chosen topic. In fact, most teachers give the students the freedom to choose the topic of their writing, provided that the students write in accordance with the genre taught or determined. Sometimes, however, a topic or theme is also related to other subjects like biology, sports, and history when the students are learning descriptive paragraph. For instance, the students are asked to describe the digestive system or a prominent figure in history.

Finally, regarding word processing, the teachers explained that they do not specifically incorporate this element into their teaching process. Even so, some teachers said that sometimes they ask their students to do writing assignments using computers, especially for writing the final draft. The reasons given are to make their writing product neat, to control the discipline of students, and to train their computer skills. In most cases, however, the teachers give the students the freedom to complete the task typed or handwritten, which suggests that the teachers do not see word processing as crucial to improving students' writing skills. This condition may need further consideration because research indicates that word processing has positive effects on writing quality (Li \& Cumming, 2001).

\section{CONCLUSION}

In this paper we have shown that using important strategies of writing instructions has been part of the writing instructions of the English teachers at a senior high school in Surabaya Indonesia. The teachers, as revealed during 
the interview, frequently make use of such strategies as collaborative writing, sentence combining, prewriting, study of writing models, and inquiry activities. They also teach their students writing strategies, ask them to write a summary, and explain to them about the purpose of their writing tasks. We believe that the English teachers have demonstrated their ability and commitment to teaching writing skills to their teenage students despite some constraints like big classes and limited time available for writing. Indeed, the teachers are experienced and resourceful in teaching English at a senior high school.

\section{REFERENCES}

Brown, H. D. (2007). Teaching by Principles: An Interactive Appraoch to Language Pedagogy (3rd Ed.). New York: Longman.

Dean, D. (2010). What Works in Writing Instruction: Researh and Practices. National Council of Teachers of English.

Dobao, A. F. (2012). Collaborative writing tasks in the L2 classroom: Comparing group, pair, and individual work. Journal of Second Language Writing 21, 40-58.

Dovey, T. (2010). Facilitating writing from sourcess: A focus on both process and product. Journal of English for Academic Purposes 9, 45-60.

Epting, L. K., Gallena, E. M., Hicks, S. A., Palmer, E. N., \& Weisberg, T. (2013). Read and think before you write: Prewriting time and level of print exposure as factors in writing and revision. Journal of Writing Research, 4(3), 239-259.

Espada-Gustilo, L. (2009). Sentence-level Errors in ESL Writers' Diagnostic Essays: What students have achieved and what we can do. Phillipine ESL Journal, 3, 108-126.

Graham, S., \& Perin, D. (2007). Writing Next: Effective Strategies to Improve Writing of Adolescents in Middle and High Schools - A report to Carnegie Corporation of New York. Washington, DC: Alliance of Excellent Education.

Harmer, J. (2007). The Practice of English Language Teaching (4th Ed.). New York: Longman. 
Jurianto, Salimah, \& Kawry, D.A., Strategies for Teaching Writing in EFL Class 53 at a Senior High School in Indonesia

Hyland, K. (2007). Genre pedagogy: Language, literacy and L2 writing instruction. Journal of Second Language Writing 16, 148-164.

Kuo, V. (2006). Adressing the issue of teaching English as a lingua franca. ELT Journal, 60(3), 213-221.

Lee, I. (1997). ESL Learners' performance in error correction in writing: Some implications for teaching. System 25(4), 465-477.

Li, J., \& Cumming, A. (2001). Word processing and second language writing: A longitudinal case study. International Journal of English studies 1(2), $127-152$.

Lin, B. (2006). Genre-based teaching and Vygotskian principles in EFL: The case of a university writing course. Asian EFL Jurnal, 8(3), 226-248.

Radia, P., \& Stapleton, P. (2008). Unconventional Internet genres and their impact on second language undergraduate students' writing process. Internet and Higher Education, 11, 9-17.

Shehadah, A. (2011). Effects and student perceptions of collaborative writing in L2. Journal of Second Language Writing 20, 286-305.

Storch, N. (2005). Collaborative writing: Product, process, and students' reflections. Journal of Second Language Writing 14, 153-173.

Weigle, S. C. (2005). Second language writing expertise. In K. Johnson, Expertise in Second Language Learning and Teaching (pp. 128-149). Hampshire: Palgrave Macmillan.

Zhang, Y. (2004). A study of English writing by native Chinese freshmen: Teaching English requires the teaching of culture(s). Asian EFL Journal, $6(4), 1-26$. 